\title{
Development and Evaluation of Instant Clove Basil Soup (ocium gratssimum)
}

\author{
Gbenga Isaac Oluwafemi* Ebenezer Idowu Oluwasola Kunle Adesina \\ Department of Food Technology \\ The Federal Polytechnic Ado-Ekiti, P.M.B. 5351 Ado-Ekiti, Ekiti State, Nigeria
}

\begin{abstract}
This study maximized the possibility of producing instant soup from underutilized vegetable: clove basil leaf and some other spices as recipe. This will stand as a better substitute for time consuming soup preparation of basil soup. Instant basil leaf soup was evaluated for chemical and the antioxidants composition such as: $\mathrm{pH}$, Total Titratable Acidity, Vitamin A and the phytochemical composition of the product. The $\mathrm{pH}$ ranged between 6.70 to 6.90; vitamin A ranged between 417.20 and 443.17 $\mu \mathrm{g}$; Total titratable acidity ranged between 0.62 and 1.38 . The phytate content ranged between 1.19 and $1.66(\mathrm{mg} / 100 \mathrm{~g})$; oxalate content ranged between 15.89 and 16.99; tannin content ranged between 0.93 and 1.45; saponin content ranged between 12.52 and 15.07. The DPPH ranged between 190.54 and $228(\mu \mathrm{g} / \mathrm{g})$; ABTS ranged between 211.11 and 255.23( $\mu \mathrm{g} / \mathrm{g})$; FRAP ranged between 30.12 and $42.11\left(\mathrm{nmolFe} \mathrm{F}^{2+} / \mathrm{mg}\right)$ However, due to the beneficial bioactive compound present in instant basil soup it should be encouraged among children and adult where vitamin A is deficient to improve eye sight and protein malnutrition. Keywords: Sensory, titratable, acidity, vitamin, malnutrition, antioxidants
\end{abstract}

DOI: $10.7176 / F S Q M / 99-05$

Publication date:July $31^{\text {st }} 2020$

\subsection{Introduction}

Soup is a primary liquid food, generally served warm or hot, that is made by combining vegetables with stock and some thickening agents and fall under heterogeneous category of food. Instant soup is almost ready to eat and take less time to cook. It has an important role for maintain nutrition of the people by covering wide range of dried foods (Ranjeet et al., 2019). Soup is also basically a liquid heterogeneous traditional food which is an appetizer, warm and healthy food during cold and sickness (Vipandeep and Kamaljit, 2019). Thick soups are prepared by mixing powder of cereal or pulse flour, cream and eggs (Radha et al., 2015). On the other hand, clear soups are made from clear extracts of plant parts and animal which are edible. Instant soup is almost ready to eat and take less time to cook (Karthika Devi et al., 2016). It has an important role for maintaining nutrition of the people by a wide range of dried foods Sarker et al., 2017). There is a big demand of instant soup mixes in the global market most among working class people. Generally commercial production of instant soup majorly depends on the physiochemical properties and the time of preparation (Abdel-Haleem and Omran, 2014). The deficiency of some antioxidants and minerals can be minimized by supplying instant basil or other vegetable soup since it can provide appreciable mentionable amount of nutrient to the diet (Sudarsan et al., 2017). Soup is generally served warm or hot but may be cool or cold, that is made by combining ingredients of meat or vegetables with stock, or water. Hot soups -are additionally characterized by cooking solid ingredients in liquids in a pot until the flavours are extracted in form of extract forming a broth. Soups are similar to stews, and in some cases, there may not be a clear distinction between the two; however, soups generally have more liquid than stews. (Goltz, 2008).

Instant soup is a type of soup designed for fast and simple preparation. Some are home-made and some are mass produced on an industrial scale and treated in various ways to preserve them for future use. A wide variety of types, styles and flavors of instant soups exist. Commercial instant soups are usually dried or dehydrated, canned, or treated by freezing. Commercial instant soups are manufactured in several types. Some consist of a packet of dry soup stock, these do not contain water, and are prepared by adding water and then heating the product for a short time, or by adding hot water directly to the dry soup mix. Instant soup can also be produced in a dry powder form, such as Unilever's Cupa-Soup Canned (tinned) instant soups contain liquid soup that is prepared by heating their contents. Some canned soups are condensed, and require instant soup in a powder form additional water to bring them to their intended strength, while others are canned in a ready-to eat, single-strength form. (Genovese, 2007). Instant noodle soups such as Cup Noodles contain dried instant ramen noodles, dehydrated vegetable and meat products, and seasonings, and are prepared by adding hot water. Packaged instant ramen noodle soup is typically formed as a cake, and often includes a seasoning packet that is added to the noodles and water during preparation. (Ziegler, 2008). Man consumes plants for several reasons but primarily for their nutritional and medicinal values. Plant parts are considered valid when consumed as food or used as medicine; based on this function they are differentiated from one another.

Scent leaves (Ocimum gratissimum) are an aromatic medicinal plant. They are typically subjected to sundrying or ambient drying as the case maybe as a mean of preservation, before its final consumption in close likeness of freshly harvested vegetables in soups. It is a perennial herb of about 1-3 $\mathrm{m}$ tall with erect stem and round 
quadrangular shape belonging to the Labiatae family in the tropics of Africa and Asia. It is a well-known plant used for medicine and processed eatable vegetable. Its highly perishability and non-availability during drying season makes its preservation highly desirable, which requires processing treatments to avoid post-harvest losses. The leaves are oftentimes referred to as Basil fever plant or tea bush and in Nigeria, Daidoya ta gida (Hausa), Nehonwu (Igbo), Tanmotswangi-wawagi (Nupe) and Efinrin (Yoruba). (Abdullahi et al, 2003). There are so many studies have already done on instant soup but a few studies on instant vegetable soup. The study is intended to fill the gap by exploring the finding related to instant fish or meat soup mix. The objectives of this project work are to produce and evaluate the nutritional quality of the instant soup produced from basil leaf.

\subsection{Materials and methods}

\subsection{Collection of samples}

The materials used in this study include matured basil leaf (scent leaf) obtained from the demonstration farm of Agricultural Technology Department Federal Polytechnic Ado Ekiti. Other ingredients used were onion, salt, locust beans, pepper, ginger, turmeric, garlic, and cray fish obtained from bisi market Ado-Ekiti Ekiti State.

\subsection{Production of instant scent leaf powder}

The matured scent leaf was sorted, cleaned, and dried at room temperature $\left(25^{\circ} \mathrm{C}\right)$ and then milled into powder using an electronic blender. Other ingredient such as onion, ginger, pepper, turmeric, garlic, Cray fish, locust bean were also sorted, cleaned, and dried in a hot air oven at $60^{\circ} \mathrm{C}$ and then milled into powder with addition of salt.

\subsection{Formulation of instant soup powder}

The formulation of the instant scent leaf soup was achieved by the mixture of the recipe (healthy) in accurate proportion. Levels of matured scent leaf, onion, ginger, garlic, cray fish, pepper, and turmeric were followed as described by (Abdel-Haleem and Omran, 2014) with some modifications. Soup mix formulations were prepared by dry mixing all the ingredients, different blends were tested for soup making quality. Soup was prepared by taking soup mix to hot water $\left(45^{0} \mathrm{c}\right)$ in the ratio 1:10 which was done for 2 to $3 \mathrm{~min}$.

Table 1: Basil Instant Soup Recipe Formulation

\begin{tabular}{llllllllll}
\hline Sample & Scent leaf & Locust bean & Garlic & Turmeric & Onion & Cray fish & Salt & Pepper & Ginger \\
\hline A & $60 \mathrm{~g}$ & $5 \mathrm{~g}$ & $25 \mathrm{~g}$ & $2 \mathrm{~g}$ & $2 \mathrm{~g}$ & $2 \mathrm{~g}$ & $2 \mathrm{~g}$ & $2 \mathrm{~g}$ & Nil \\
$\mathrm{B}$ & $65 \mathrm{~g}$ & $5 \mathrm{~g}$ & Nil & $2 \mathrm{~g}$ & $2 \mathrm{~g}$ & $2 \mathrm{~g}$ & $2 \mathrm{~g}$ & $2 \mathrm{~g}$ & $20 \mathrm{~g}$ \\
$\mathrm{C}$ & $70 \mathrm{~g}$ & $5 \mathrm{~g}$ & $15 \mathrm{~g}$ & $2 \mathrm{~g}$ & $2 \mathrm{~g}$ & $2 \mathrm{~g}$ & $2 \mathrm{~g}$ & $2 \mathrm{~g}$ & Nil \\
$\mathrm{D}$ & $75 \mathrm{~g}$ & $5 \mathrm{~g}$ & Nil & $2 \mathrm{~g}$ & $2 \mathrm{~g}$ & $2 \mathrm{~g}$ & $2 \mathrm{~g}$ & $2 \mathrm{~g}$ & $10 \mathrm{~g}$ \\
$\mathrm{E}$ & $80 \mathrm{~g}$ & $10 \mathrm{~g}$ & Nil & $2 \mathrm{~g}$ & $2 \mathrm{~g}$ & $2 \mathrm{~g}$ & $2 \mathrm{~g}$ & $2 \mathrm{~g}$ & Nil \\
\hline
\end{tabular}

KEY: Sample A $=60 \%$ Basil leaf powder $+5 \%$ Locust bean $+25 \%$ Garlic $+2 \%$ turmeric $+2 \%$ Onion $+2 \%$ cray fish $+2 \%$ salt $+2 \%$ red pepper $+0 \%$ ginger

Sample B $=65 \%$ Basil leaf powder $+5 \%$ Locust bean $+0 \%$ Garlic $+2 \%$ turmeric $+2 \%$ Onion $+2 \%$ cray fish $+2 \%$ salt $+2 \%$ red pepper $+20 \%$ ginger

Sample C $=70 \%$ Basil leaf powder $+5 \%$ Locust bean $+15 \%$ Garlic $+2 \%$ turmeric $+2 \%$ Onion $+2 \%$ cray fish $+2 \%$ salt $+2 \%$ red pepper $+0 \%$ ginger

Sample D $=75 \%$ Basil leaf powder $+5 \%$ Locust bean $+0 \%$ Garlic $+2 \%$ turmeric $+2 \%$ Onion $+2 \%$ cray fish $+2 \%$ salt $+2 \%$ red pepper $+10 \%$ ginger

Sample E $=80 \%$ Basil leaf powder $+10 \%$ Locust bean $+0 \%$ Garlic $+2 \%$ turmeric $+2 \%$ Onion $+2 \%$ cray fish $+2 \%$ salt $+2 \%$ red pepper $+0 \%$ ginger

\subsection{Chemical composition:}

\subsection{1 pH determination}

After calibration the $\mathrm{pH}$ meter with the buffers, the electrode(s) and glassware were rinsed with distilled water. $1 \mathrm{~g}$ of each of the sample was carefully measured and place in a $150 \mathrm{ml}$ beaker for the $\mathrm{pH}$ determination. The rinsed electrode was placed in the test sample. All the samples were allowed to come to room temperature in the tightly capped bottle. The sample was stirred very gently and the $\mathrm{pH}$ was determined recorded to the nearest 0.01 .

\subsubsection{Determination Vitamin A}

$50 \mathrm{ml}$ of $0.2 \mathrm{M}$ of $\mathrm{H}_{2} \mathrm{So} 4$ was added to $1 \mathrm{~g}$ of each of the sample boiled on a water bath and cooled. $1 \mathrm{ml}$ of $0.5 \mathrm{M}$ of HCL was added and filtered. $10 \mathrm{ml}$ from each filtered sample was poured into each of the test tube labeled test tube $\mathrm{A}$ and B. $1.0 \mathrm{ml}$ of water was added to test tube $\mathrm{A}$ and $1 \mathrm{ml}$ of acetic acid was added to both tubes mixed together and then $0.5 \mathrm{ml}$ of $3 \% \mathrm{kmno}_{4}$ was added and then kept away for 2 minutes. Thereafter $0.5 \mathrm{ml}$ of $3 \%$ of $\mathrm{H}_{2} \mathrm{O}_{2}$ was added. The adsorbent was read using spectrophotometer at $470 \mathrm{NM}$ and $525 \mathrm{~mm}$, a blank was prepared, readings of the result was noted and recorded. (AOAC, 2012)

\subsubsection{Total Titratable Acidity determination}

According to (AOAC, 2012) $1 \mathrm{~g}$ instant basil soup was dissolved $100 \mathrm{ml}$ of distilled water, $1 \mathrm{ml}$ from the solution 
was titrated with $0.1 \mathrm{~N} \mathrm{NaoH}$ to an end point using phenolphthalen indicator and the volume of NaoH used was recorded. The titratable acidity was calculated as: $\%$ acid $=(\mathrm{mls} \mathrm{NaOH}$ used $\times 0.1 \mathrm{~N} \mathrm{NaoH} \times$ millequivalent factor x 100)/weight of sample

\subsubsection{Determination of Phytate}

The phytic acid content was determined using a modified indirect colorimetric method according to (Burbano et al., 1999). The method depends on an Iron to phosphorus ratio of 4:6 and is based on the ability of standard ferric chloride to precipitate phytate in dilute HCI extract of the sample. $5 \mathrm{~g}$ of the sample was extracted with $20 \mathrm{ml}$ of $3 \%$ trichloroacetic acid and filtered. $5 \mathrm{ml}$ of the filtrate was used for the analysis; the phytate was precipitated as ferric phytate and converted to ferric hydroxide and soluble sodium phytate by adding $5 \mathrm{ml}$ of IM NaOH. The precipitate was dissolved with hot $3.2 \mathrm{M} \mathrm{HNO} 3$ and the absorbances were read immediately at $480 \mathrm{~nm}$. Preparation of standard curve for phytic acid was done as follows: standard curve of different $\mathrm{Fe}\left(\mathrm{NO}_{3}\right) 3$ concentrations was plotted against the corresponding absorbance of spectrophotometer to calculate the ferric iron concentration. The phytate phosphorus was calculated from the concentration of ferric iron assuming 4:6 iron: phosphorus molar ratio.

\subsubsection{Determination of Tannins}

Tannin was extracted into boiling distilled water for one hour. Colour development was done with Folin-Dennis reagent and sodium carbonate solution. Absorbance was measured at $750 \mathrm{~nm}$ spectrophotometrically. The tannic acid concentrations were calculated from the tannic acid standard curve (AOAC, 2012).

\subsubsection{Determination of Oxalate}

This was determined using Dye method (AOAC, 2012). $2 \mathrm{~g}$ each of the samples was extracted with dilute $\mathrm{HCl}$, $10 \mathrm{ml}$ concentrated ammonia and then precipitated with calcium chloride as calcium oxalate. The precipitate was then washed with $25 \mathrm{ml}$ of hot $25 \% \mathrm{H}_{2} \mathrm{SO}_{4}$ and dissolved in hot water and titrated with $0.05 \mathrm{M} \mathrm{KMnO} 4$ to determine the concentration of oxalate.

\subsection{Antioxidants Properties}

\subsubsection{Ferric reducing antioxidant power (FRAP) assay}

FRAP assay was performed according to the methods of (Dehshahri et al., 2012) with slight modification. An amount of $200 \mu \mathrm{l}$ extracted samples were mixed with $3 \mathrm{~mL}$ FRAP reagent in test tubes and undergoes vortex. Blank samples were prepared for both methanol and deionized water extracted samples. Both samples and blank were incubated in water bath for 30 minutes at $37^{\circ} \mathrm{C}$ and the absorbance of the samples was determined against blank at $593 \mathrm{~nm}$.

\subsubsection{DPPH Radical Scavenging Assay}

Antioxidant activity was determined with 1,1-diphenyl-2- picryl-hydrazil (DPPH) to measure the scavenging activity of the free radicals (Kaur et al., 2019). Samples $(1 \mathrm{~g})$ were extracted for $4 \mathrm{~h}$ at $30 \pm 1 \mathrm{C}$ with $50 \mathrm{ml}$ of $80 \%(\mathrm{w} / \mathrm{v})$ methanol in an orbital shaker. The obtained extract after shaking was centrifuged at $10,000 \mathrm{rpm}$ for 10 min. The supernatant was collected, from that $1.0 \mathrm{ml}$ was mixed with $1.0 \mathrm{ml}$ of tris buffer in a test tube. In the mixture, $2.0 \mathrm{ml}$ of DPPH was added and incubated for $30 \mathrm{~min}$ in the dark at room temperature conditions. Methanol was used as control and the absorbance was measured at $517 \mathrm{~nm}$.

\subsubsection{ABTS assay}

The ABTS stock solution was diluted with $67 \%$ methanol to the absorbance of 0.70 at $734 \mathrm{~nm}$.Apprppriate solvent blank was used in each assay. The standard curve was determined in the range of $0.1-2.5 \mathrm{~m} \mathrm{M}$. The measurements were performed by a spectrophotometer UV-T60U PG instrument.

\subsection{Statistical Analysis}

The difference in experimental data was tested for statistical significance $p \leq 0.05$ by Statistical Analysis of Variance (ANOVA) using SPSS 23.0 software package (Statistical Package for Social Scientist, Michigan, USA)

\subsection{Results and Discussion \\ 3.1 Chemical composition}

Chemical compositions of the instant basil soup are presented in Table 2. The total titratable acidity ranged between 0.62 and 1.38. All the samples were significantly different ( $\mathrm{p}>0.05)$ from one another. Sample D had the least TTA value (0.62) while sample A had the highest TTA (1.38) value. The low total titratable acidity in sample $\mathrm{D}$ could be as a result of zero percentage of garlic in the formulation while the high level of TTA in sample A could be as a result of the high percentage of garlic acid in the formulation being a good source of acid to the sample and the antifungal, antibacterial, cardiac protective and antioxidant properties which could lead to reduction in Acidity of the instant soup (Ayoka et al., 2016). The $\mathrm{pH}$ of the samples ranged between 6.70 and 6.90. Although sample A, C and D were not significantly $(\mathrm{p}>0.05)$ different from one another but significantly $(\mathrm{p}>0.05)$ higher than sample B and E. The low level of $\mathrm{pH}$ could be as a result of the zero percentage of garlic acid present in their formulation. However, from the result it was observed that variation in the percentage of basil leaves does not have effect on the total titratable acidity and $\mathrm{pH}$ of the samples. Vitamin A value ranged between 417 and 427 
across the samples. Sample A, B and D were significantly ( $p>0.05$ ) lower compare to sample C and E. Although there was a uniform percentage of turmeric powder used across the samples which serve as a good source of vitamin due to the yellow pigment present in the plant. Moreso, as the proportion of the basil increases the percentage of Vitamin A increases likewise.

Table 2. chemical composition of Instant basil soup

\begin{tabular}{llll}
\hline Sample & TTA \% & PH & Vitamin A (IU) \\
\hline A & $1.38 \pm 0.03^{\mathrm{a}}$ & $6.86 \pm 0.05^{\mathrm{a}}$ & $417 \pm 0.10^{\mathrm{b}}$ \\
B & $1.30 \pm 0.01^{\mathrm{b}}$ & $6.70 \pm 0.05^{\mathrm{c}}$ & $424 \pm 0.10^{\mathrm{b}}$ \\
C & $0.89 \pm 0.01^{\mathrm{c}}$ & $6.90 \pm 0.01^{\mathrm{a}}$ & $435 \pm 10.09^{\mathrm{a}}$ \\
D & $0.62 \pm 0.02^{\mathrm{e}}$ & $6.90 \pm 0.01^{\mathrm{a}}$ & $419 \pm 0.78^{\mathrm{b}}$ \\
E & $0.70 \pm 0.01^{\mathrm{d}}$ & $6.79 \pm 0.36^{\mathrm{b}}$ & $427 \pm 11.10^{\mathrm{a}}$ \\
\hline
\end{tabular}

All data were mean \pm standard deviation of triplicate determinations

Means within the same column with the same subscripts were not significantly different.

Sample A $=60 \%$ Basil leaf powder $+5 \%$ Locust bean $+25 \%$ Garlic $+2 \%$ turmeric $+2 \%$ Onion $+2 \%$ cray fish $+2 \%$ salt $+2 \%$ red pepper $+0 \%$ ginger

Sample B $=65 \%$ Basil leaf powder $+5 \%$ Locust bean $+0 \%$ Garlic $+2 \%$ turmeric $+2 \%$ Onion $+2 \%$ cray fish $+2 \%$ salt $+2 \%$ red pepper $+20 \%$ ginger

Sample C $=70 \%$ Basil leaf powder $+5 \%$ Locust bean $+15 \%$ Garlic $+2 \%$ turmeric $+2 \%$ Onion $+2 \%$ cray fish $+2 \%$ salt $+2 \%$ red pepper $+0 \%$ ginger

Sample D $=75 \%$ Basil leaf powder $+5 \%$ Locust bean $+0 \%$ Garlic $+2 \%$ turmeric $+2 \%$ Onion $+2 \%$ cray fish $+2 \%$ salt $+2 \%$ red pepper $+10 \%$ ginger

Sample E $=80 \%$ Basil leaf powder $+10 \%$ Locust bean $+0 \%$ Garlic $+2 \%$ turmeric $+2 \%$ Onion $+2 \%$ cray fish $+2 \%$ salt $+2 \%$ red pepper $+0 \%$ ginger

\subsection{Phytochemical composition}

Phytochemical compositions of the instant basil soup are presented in Table 3. Phytate ranged between 1.19 and $1.66(\mathrm{mg} / 100 \mathrm{~g})$. The phytate value of sample A was significantly $(\mathrm{p}>0.05)$ higher compare to other samples, although not significantly $(\mathrm{p}<0.05)$ different from sample $E$ which is an indication that increasing the proportion of basil leaf powder those not have effect on the phytate composition of the basil instant soup. Reduction in the phytate content is could be due to their water-soluble property which may occur through leaching. Oxalate content ranged between 15.89 and $16.99(\mathrm{mg} / 100 \mathrm{~g})$. There was no significant $(\mathrm{p}<0.05)$ difference as the percentage of basil leaf powder increases from 60 to $70 \%$ even with the reduction of the percentage of garlic but it increases as the basil leaf powder increases from $70-75 \%$ in sample D and $75-80 \%$ in sample E. However, sample D and E were not significantly $(\mathrm{p}<0.05)$ different. Tannin content of instant basil soup ranged between 0.93 and $1.45(\mathrm{mg} / 100 \mathrm{~g})$, as the basil leaf powder increases in the formulation the tannin content increases as well which is an indication that tannin is predominant in vegetable leafy food such as basil leaf. Saponin is known to be a bitter component in plants. Saponin content of the instant basil soup ranged between 12.52 and $15.07(\mathrm{mg} / 100 \mathrm{~g})$. Sample E had the highest saponin content which could be as a result of the high percentage of basil leaf powder and the zero level of garlic and ginger present in the formulation.

Table 3: Phytochemical composition of Instant basil soup

\begin{tabular}{lllll}
\hline Sample & $\begin{array}{l}\text { Phytate } \\
(\mathrm{mg} / 100 \mathrm{~g})\end{array}$ & $\begin{array}{l}\text { Oxalate } \\
(\mathrm{mg} / 100 \mathrm{~g})\end{array}$ & $\begin{array}{l}\text { Tannin } \\
(\mathrm{mg} / 100 \mathrm{~g})\end{array}$ & $\begin{array}{l}\text { Saponin } \\
(\mathrm{mg} / 100 \mathrm{~g})\end{array}$ \\
\hline A & $1.66^{\mathrm{a}} \pm 0.04$ & $15.89^{\mathrm{b}} \pm 0.02$ & $0.93^{\mathrm{c}} \pm 0.01$ & $14.19^{\mathrm{b}} \pm 0.01$ \\
$\mathrm{~B}$ & $1.19^{\mathrm{b}} \pm 0.01$ & $16.39^{\mathrm{b}} \pm 0.02$ & $1.00^{\mathrm{c}} \pm 0.02$ & $12.52^{\mathrm{cd}} \pm 0.02$ \\
$\mathrm{C}$ & $1.20^{\mathrm{b}} \pm 0.08$ & $16.42^{\mathrm{b}} \pm 0.12$ & $1.29^{\mathrm{b}} \pm 0.02$ & $12.84^{\mathrm{c}} \pm 0.03$ \\
$\mathrm{D}$ & $1.25^{\mathrm{b}} \pm 0.06$ & $16.92^{\mathrm{a}} \pm 0.19$ & $1.32^{\mathrm{b}} \pm 0.01$ & $14.52^{\mathrm{b}} \pm 0.03$ \\
E & $1.59^{\mathrm{a}} \pm 0.11$ & $16.99^{\mathrm{a}} \pm 0.01$ & $1.45^{\mathrm{a}} \pm 0.01$ & $15.07^{\mathrm{a}} \pm 0.03$ \\
\hline
\end{tabular}

All data were mean \pm standard deviation of triplicate determinations

Means within the same column with the same subscripts were not significantly different.

Sample A $=60 \%$ Basil leaf powder $+5 \%$ Locust bean $+25 \%$ Garlic $+2 \%$ turmeric $+2 \%$ Onion $+2 \%$ cray fish $+2 \%$ salt $+2 \%$ red pepper $+0 \%$ ginger

Sample B $=65 \%$ Basil leaf powder $+5 \%$ Locust bean $+0 \%$ Garlic $+2 \%$ turmeric $+2 \%$ Onion $+2 \%$ cray fish $+2 \%$ salt $+2 \%$ red pepper $+20 \%$ ginger

Sample C $=70 \%$ Basil leaf powder $+5 \%$ Locust bean $+15 \%$ Garlic $+2 \%$ turmeric $+2 \%$ Onion $+2 \%$ cray fish $+2 \%$ salt $+2 \%$ red pepper $+0 \%$ ginger

Sample D $=75 \%$ Basil leaf powder $+5 \%$ Locust bean $+0 \%$ Garlic $+2 \%$ turmeric $+2 \%$ Onion $+2 \%$ cray fish $+2 \%$ salt $+2 \%$ red pepper $+10 \%$ ginger

Sample E $=80 \%$ Basil leaf powder $+10 \%$ Locust bean $+0 \%$ Garlic $+2 \%$ turmeric $+2 \%$ Onion $+2 \%$ cray fish $+2 \%$ 
salt $+2 \%$ red pepper $+0 \%$ ginger

\subsection{Antioxidant composition}

Antioxidants composition of the instant basil soup are presented in Table 4. The DPPH radical-scavenging activity ranged between 190.54 and $232.09(\mu \mathrm{g} / \mathrm{g})$ across the samples. There was a significant difference $(\mathrm{P}<0.05)$ among the samples. Sample A had the least value $190.54(\mu \mathrm{g} / \mathrm{g})$ of DPPH which could be as a result of the low percentage of basil powder in the formulation while the highest value was noticed in sample E $228.30(\mu \mathrm{g} / \mathrm{g})$, the high value could be as a result of the high proportion of basil leaf powder. Most vegetables are known to be very rich in plant antioxidants such as DPPH. ABTS is a stable radical soluble in water and organic solvents. The ABTS of the instant basil soup ranged between 211.11 and $255.23(\mu \mathrm{g} / \mathrm{g})$. There was a significant difference $(\mathrm{P}>0.05)$ among the samples and it was observed that the ABTS antioxidant reduces as the basil leaf powder increases with lower percentage of garlic in the instant soup formulation. Sample D $(211.11, \mu \mathrm{g} / \mathrm{g})$ had the lowest value but not significantly $(\mathrm{P}>0.05)$ different from sample $\mathrm{E}(212.68, \mu \mathrm{g} / \mathrm{g})$, this could be as a result of the same formulation used in the recipe except the basil leaf powder with little variation in their quantity $(5 \%)$ which might not cause any significant change in their ABTS value. FRAP assay measures the antioxidants effects of any substance in the reaction medium as reducing ability. The FRAP content ranged between 30.12 and 42.11 (nmol Fe2+/mg), The FRAP assay reduces as the percentage of basil leaf powder increases in the formulation. The basil instant soup formulation with $60 \%$ basil leaf powder and $25 \%$ garlic had the highest FRAP assay $(42.11, \mathrm{nmol} \mathrm{Fe} 2+/ \mathrm{mg})$ value but not significantly $(\mathrm{P}>0.05)$ different from samples $\mathrm{B}(40.07$, nmol Fe2+/mg) and $\mathrm{C}(34.52, \mathrm{nmol} \mathrm{Fe} 2+/ \mathrm{mg})$ except for sample D and E. Variation in the percentage of garlic and ginger in the formulation does not have effect on the FRAP assay except for the percentage of basil leaf powder.

Table 4: Antioxidants properties of Instant basil soup

\begin{tabular}{lcccl}
\hline Sample & DPPH & $\boldsymbol{( \mu \mathbf { g } / \mathbf { g } )}$ & \multicolumn{1}{c}{ ABTS $(\boldsymbol{\mu g} / \mathbf{g})$} & FRAP $(\mathbf{n m o l ~ F e 2 + / m g})$ \\
\hline A & $190.54^{\mathrm{a}} \pm 0.06$ & $255.23^{\mathrm{a}} \pm 0.15$ & $42.11^{\mathrm{a}} \pm 0.02$ \\
B & $208.32^{\mathrm{d}} \pm 0.13$ & $234.29^{\mathrm{b}} \pm 0.23$ & $40.07^{\mathrm{a}} \pm 0.09$ \\
$\mathrm{C}$ & $215.21^{\mathrm{c}} \pm 0.21$ & $218.15^{\mathrm{c}} \pm 0.14$ & $34.52^{\mathrm{a}} \pm 0.11$ \\
$\mathrm{D}$ & $219.07^{\mathrm{b}} \pm 0.08$ & $211.11^{\mathrm{d}} \pm 0.09$ & $32.46^{\mathrm{b}} \pm 0.05$ \\
E & $228.30^{\mathrm{a}} \pm 0.17$ & $212.68^{\mathrm{d}} \pm 0.11$ & $30.12^{\mathrm{b}} \pm 0.01$ \\
\hline
\end{tabular}

All data were mean \pm standard deviation of triplicate determinations

Means within the same column with the same subscripts were not significantly different.

Sample A $=60 \%$ Basil leaf powder $+5 \%$ Locust bean $+25 \%$ Garlic $+2 \%$ turmeric $+2 \%$ Onion $+2 \%$ cray fish $+2 \%$ salt $+2 \%$ red pepper $+0 \%$ ginger

Sample B $=65 \%$ Basil leaf powder $+5 \%$ Locust bean $+0 \%$ Garlic $+2 \%$ turmeric $+2 \%$ Onion $+2 \%$ cray fish $+2 \%$ salt $+2 \%$ red pepper $+20 \%$ ginger

Sample C $=70 \%$ Basil leaf powder $+5 \%$ Locust bean $+15 \%$ Garlic $+2 \%$ turmeric $+2 \%$ Onion $+2 \%$ cray fish $+2 \%$ salt $+2 \%$ red pepper $+0 \%$ ginger

Sample D $=75 \%$ Basil leaf powder $+5 \%$ Locust bean $+0 \%$ Garlic $+2 \%$ turmeric $+2 \%$ Onion $+2 \%$ cray fish $+2 \%$ salt $+2 \%$ red pepper $+10 \%$ ginger

Sample E $=80 \%$ Basil leaf powder $+10 \%$ Locust bean $+0 \%$ Garlic $+2 \%$ turmeric $+2 \%$ Onion $+2 \%$ cray fish $+2 \%$ salt $+2 \%$ red pepper $+0 \%$ ginger

\subsection{CONCLUSION}

The basil leaf powder enriched soup mixes possessed an excellent antioxidant activity. It could be concluded that basil leaves powder can be effectively used in the preparation of nutritious soup powder by proper processing and optimizing the level of other ingredients in appropriate proportion. The health benefits of basil leaves powder are well known due to the chemical composition, so this instant soup can act as a supplementary food and can satisfy the daily standard requirements for consumption. Moreover, the suitable use of alternative vegetable leaves such as basil leaves in the form of vegetable leaf powder can be an effective effort in achieving the nutritional security of masses at low cost. It is recommended that the consistent instant soup mix formulations, if incorporated in regular dietary patterns it can be a healthy option for general masses owing to their high phytochemical composition and antioxidant activity in comparison to the soup mixes available in the market.

\section{ACKNOWLEDGEMENTS}

The authors are thankful to Head, Department of Food Technology Federal Polytechnic Ado Ekiti Nigeria for providing necessary laboratory facilities. Authors are also thankful to Centre for Research and Innovation Development (CRID) Federal Polytechnic Ado Ekiti for their financial support to carry out this research work and lastly to Agricultural Technology Department Federal Polytechnic Ado Ekiti for making the basil leaves available. 


\section{References}

Abdel-Haleem, A.M.H. and Omran, A.A. (2014) Preparation of Dried Vegetarian Soup Supplemented with Some Legumes. Food and Nutrition Sciences, 5, 2274-2285.

Abdullahi, M., Muhammed, G. and Abdulkadir, N.U. (2003). Medicinal and Economic Plants of Nupe Land, 1st edition pg 139.

AOAC (2012). Official Methods of Analysis of Association of Official Analytical Chemists International, 19th Ed., Gaithersburg, MD, USA.

Ayoka, A.O., Ademoye, A.K., Imafidon, C.E., Ojo, E.O. and Oladele, A.A. (2016). Aqueous extract of Allium sativum (Linn.) bulbs ameliorated pituitary-testicular injury and dysfunction in Wistar rats with $\mathrm{Pb}$ induced reproductive disturbances. Open Access Maced J Med Sci 4(2):200.

Burbano, C., Muzquiz, M., Ayet, G., Cuadrado, C., and Pedrosa, M. M. (1999). Evaluation of antinutritional factors of selected varieties of Phaseolus vulgaris. Journal of the Science Food and Agriculture, 79, 14681472 .

Dehshahri, S., Wink, M., Afsharypuor, S, Asghari, G., and Mohagheghzadeh, A. (2012). Antioxidant activity in methanolic leaf extract of moringa peregrine (Forssk) fiori. Research in Pharmaceuticals Sciences 7(2):111118.

Genovese, P. (2007). New Jersey Curiosities: Quirky Characters, Roadside Oddities and Other Offbeat Stuff. Globe Pequot. p. 174. ISBN0762741120.

Goltz, E. (2008). "Soup vs. stew: Difference in details". The Journal Gazette (Fort Wayne, Indiana).

Karthika Devi, B., Kuriakose, S.P., Krishnan, A.V.C., Choudhary, P. and Rawson, A. (2016). Utilization of ByProduct from Tomato Processing Industry for the Development of New Product. Journal of Food Processing and Technology, 7, 608.

Kaur, R., Kaur, K., and Ahluwalia, P. (2019). Effect of drying temperatures and storage on chemical and bioactive attributes of dried tomato and sweet pepper. LWT Food Sci Technol. https://doi.org/10. 1016/j.lwt.2019.108604.

Radha, C., Ogunsina, B.S. and Hebina-Babu, K.T. (2015). Some Quality and Micro-Structural Characteristics of Soup Enriched with Debittered Moringa Oleifera Seeds Flour. American Journal of Food Science and Technology, 3, 145-149.

Ranjeet, C. K., Pranit, S. M. and Yogesh P. S. (2019). Studies on Development and Standardization of Moringa Leaves Instant Soup Mix Powder Incorporated with Garden Cress Seeds International Journal of Research and Review (www.ijrrjournal.com) 242: 6: 10.

Sarker, M.N.I., Barman, S.C., Islam, M. and Islam, R. (2017). Role of Lemon (Citrus limon) Production on Livelihoods of Rural People in Bangladesh. Journal of Agricultural Economics and Rural Development, 2, 167-175.

Sudarsan, S.M., Santhanam, S.G. and Visalachi, V. (2017). Development and Formulation of Instant Soup Mix from Sprouted Horse Gram and Radish Leaves. International Journal of Home Science, 3, 346-349.

Vipandeep S. and Kamaljit K. (2019). Development, formulation and shelf life evaluation of baby corn soup mix from industrial by-product J Food Sci Technol. https://doi.org/10.1007/s13197-019-04227-1.

Ziegler, E. H (2008). Flavourings, John Wiley and Sons pp. 502-505. ISBN3527611819. 